\title{
Think beyond simple pneumonia
}

\author{
Naveen Voore, ${ }^{1}$ Rudra Beharrysingh, ${ }^{1}$ Pallavi Reddy Kuppireddy ${ }^{2}$
}

${ }^{1}$ Department of Internal Medicine, Riverside Shore Memorial Hospital, Nassawadox, Virginia, USA ${ }^{2}$ Eastern Virginia Medical School, Norfolk, Virginia, USA

\section{Correspondence to}

Dr Naveen Voore, voorenaveen@yahoo.com

Accepted 15 October 2015
CrossMark

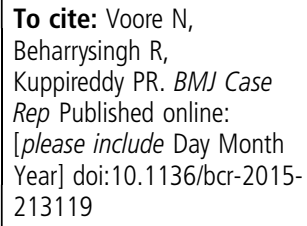

\section{DESCRIPTION}

A 30-year-old African-American man, a truck driver, with a known history of gastro-oesophageal reflux disease, presented with shortness of breath, dry cough and malaise. He was recently hospitalised for community-acquired pneumonia and treated with moxifloxacin, initially intravenously and later orally, after discharge. He felt subjectively better for a few days and then started having more symptoms, which prompted him to return to the emergency department.

On examination, he was febrile, tachycardic and tachypnoeic. On auscultation, he had coarse crackles on the right side of his lung fields. Laboratory data showed a white cell count of 18.5 , with neutrophil predominance. Chest X-ray revealed infiltrates bilaterally but most prominently on the right (figure 1). He was started on broad-spectrum antibiotics for presumed atypical or nosocomial infection. Within the next 2 days his condition deteriorated and he had more hypoxaemia and respiratory distress. He was placed in the intensive care unit and more imaging studies were obtained.

Subsequent chest X-ray and CT of the chest (figures 2 and 3 ) on day 3 of admission showed increased infiltrates involving the right middle and lower lobe compared to prior as well as new infiltrates in the left lower lobe. The patient subsequently underwent bronchoscopy on day 4 of his hospital stay. Tissue biopsies thereby obtained revealed large quantities of broad-based budding yeast most consistent with Blastomyces (figure 4). $\mathrm{He}$ was then started on intravenous amphotericin B. From that point on, his clinical status gradually improved and he was eventually discharged from

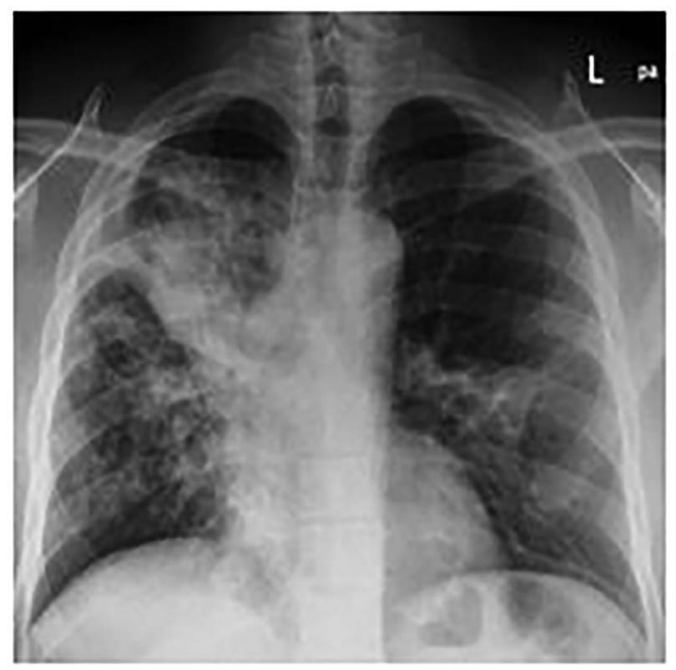

Figure 1 Initial chest X-ray on admission showing pneumonia predominantly involving the right upper lobes.

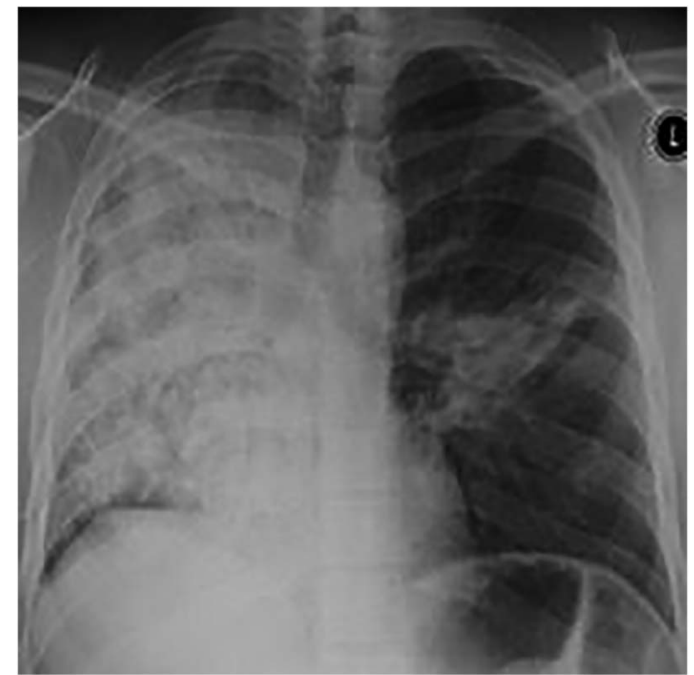

Figure 2 Chest X-ray on day 3 of admission showing worsening infiltrates in multilobar distribution.

the hospital on a 6-month course of oral itraconazole.

Blastomycosis is a chronic, granulomatous disease caused by a dimorphic fungus, Blastomyces dermatitidis. This is an endemic infection in the south-eastern, south-central and mid-western states of North America. ${ }^{1}$ Although this condition primarily affects the lungs, it can disseminate to the skin, bone, genitourinary tract and central nervous system. Clinical presentation can be variable, and ranges from asymptomatic illness to subclinical infection and chronic infection. ${ }^{2}$ The primary route of transmission is by inhalation of conidia, which

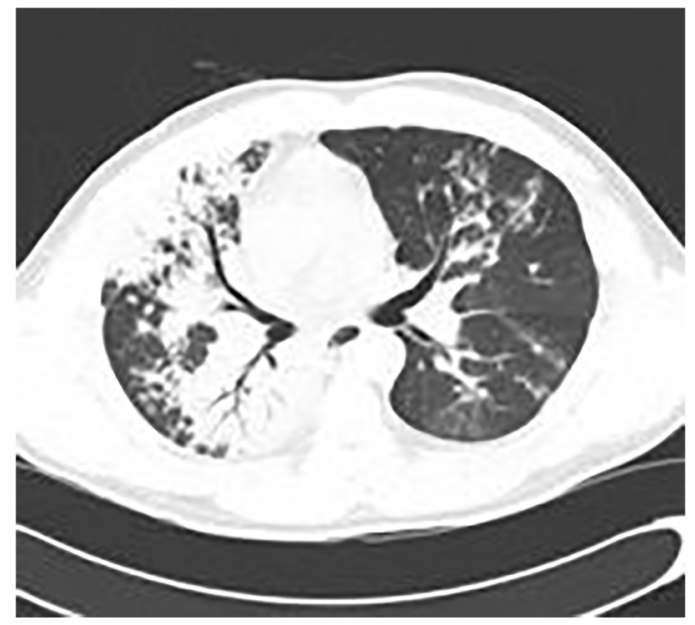

Figure $3 \mathrm{CT}$ of the chest showing infiltrates in the right side of the lungs. 


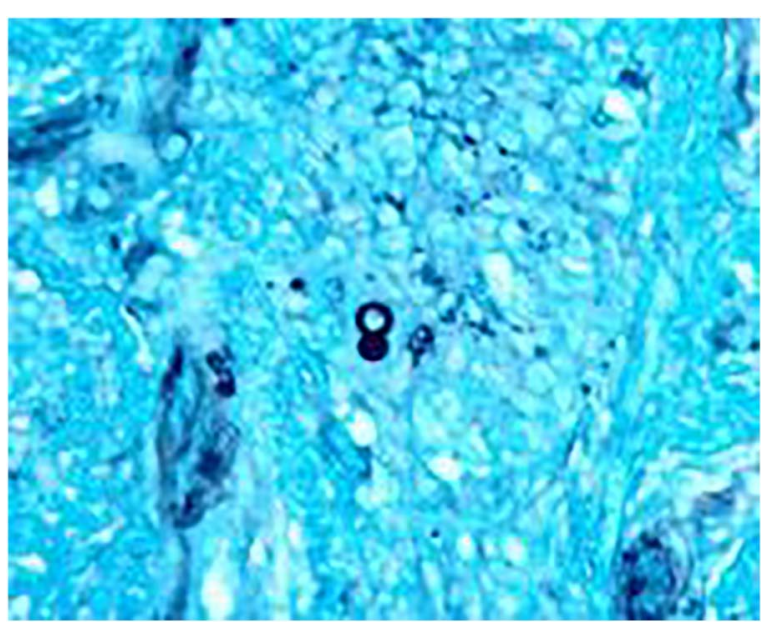

Figure 4 Periodic acid-Schiff stain of bronchial washings showing broad-based yeast.

leads to lobar or segmental lung disease. Conidia transform into yeast, which is usually a more resistant form, at body temperature.

Pulmonary blastomycosis is often indistinguishable from bacterial pneumonia. Clinicians should suspect the possibility of blastomycosis if a patient presents with treatment-refractory pneumonia or infiltrates. Symptoms of pulmonary blastomycosis usually vary based on chronicity and progression of the condition. Cough, sputum, fever and myalgias are more common in acute presentations. ${ }^{3}$ Chronic pulmonary infection presents with low intermittent fevers, night sweats, chest pain and haemoptysis. In a few cases, the course will be fulminant with rapid systemic dissemination and progression to acute respiratory distress syndrome. $^{2}$

Although some patients may require bronchoscopy, sputum microscopy and cultures should be considered. Cultures usually take 5-30 days, but time to diagnosis may be shortened if exoantigen testing or DNA probes are used. Patients with mild to moderate pulmonary blastomycosis can be treated with itraconazole. However, patients presenting with progressive pulmonary disease or disseminated infection, or those in an immune compromised state, should be treated with amphotericin B for 1-2 weeks followed by oral itraconazole for 6-12 months.

\section{Learning points}

- Pulmonary blastomycosis can be mistaken for bacterial pneumonia, tuberculosis or malignancy, since it can present as infiltrates, masses and cavitary lesions.

- Severity of the disease usually depends on the immune status of the patient, as it can be more aggressive in immunocompromised patients; but it is not an opportunistic infection in these individuals.

Contributors NV and RB were involved in patient care, and writing and editing of the manuscript. PRK was involved in reviewing and editing of the manuscript.

Competing interests None declared.

Patient consent Obtained.

Provenance and peer review Not commissioned; externally peer reviewed.

\section{REFERENCES}

1 Bradsher RW, Chapman SW, Pappas PG. Blastomycosis. Infect Dis Clin North Am 2003; 17:21-40.

2 Meyer KC, McManus EJ, Maki DG. Overwhelming pulmonary blastomycosis associated with the adult respiratory distress syndrome. $N$ Eng J Med 1993:329:1231-6.

3 Sarosi GA, Hammerman KJ, Tosh FE, et al. Clinical features of acute pulmonary blastomycosis. N Eng J Med 1974;290:540-3.

Copyright 2015 BMJ Publishing Group. All rights reserved. For permission to reuse any of this content visit http://group.bmj.com/group/rights-licensing/permissions.

BMJ Case Report Fellows may re-use this article for personal use and teaching without any further permission.

Become a Fellow of BMJ Case Reports today and you can:

- Submit as many cases as you like

- Enjoy fast sympathetic peer review and rapid publication of accepted articles

- Access all the published articles

- Re-use any of the published material for personal use and teaching without further permission

For information on Institutional Fellowships contact consortiasales@bmjgroup.com

Visit casereports.bmj.com for more articles like this and to become a Fellow 